\title{
Effect of growing seasons, plant extracts with various rates on Black Bean Aphid, Aphis Fabae (Aphididae: Homoptera)
}

\author{
Rebin A. Qadir \\ Crop protection \\ Bakrajo Technical Institute \\ Sulaimani Polytechnic University \\ Sulaimani, Iraq \\ Rebin.qadir@spu.edu.iq
}

\author{
Havall M. Amin \\ Crop Protection \\ Bakrajo Technical Institute \\ Sulaimani Polytechnic University \\ Sulaimani, Iraq \\ Havall.amin@spu.edu.iq
}

\author{
Ardalan J. Majeed \\ Ornamental Plants \\ Bakrajo Technical Institute \\ Sulaimani Polytechnic University \\ Sulaimani, Iraq \\ Ardalan.majeed@spu.edu.iq
}

\begin{abstract}
Four plant extracts: Eucalyptus (Eucalyptus sp), Onion (Allium cepa Linn), Garlic (Allium sativum) and Cinnamon (Cinnamomum sp) with three extraction rates (0, 1 and 3) \% in 2016 and 2017 seasons were used against aphid population in broad bean (Vicia faba). Some plants characteristic; Plant Height (cm), Fresh Weight.Plant ${ }^{-1}$ (g), Dry Weight.Plant $^{-1}$ (g), Number of Pods.Plant ${ }^{-1}$, and aphid's dead number after 6 hours and 24 hours were taken. Eucalyptus affected significantly on Number of Pods.Plant ${ }^{-1}$ compared with the other extraction (7.416). As the extraction rate increased, all parameters increased. Pearson's correlation test for traits in 2017 season indicated that there were a significant strong correlate and better than 2016 season among Number of Pods .Plant ${ }^{-1}$, Fresh Weight.Plant ${ }^{-1}\left(r=0.770^{* *}\right)$, Dry Weight .Plant ${ }^{-1}\left(r=0.816^{* *}\right)$, and M24 $(r=$ 871**). Based on Number of Pods.Plant ${ }^{-1}$, the best interaction between the season, extraction types, and extraction rates, was a combination of the 2017 season $\times$ Eucalyptus extraction $\times 1 \%$ Extraction rate.
\end{abstract}

Keywords: Plant Extracts, Aphis Fabae, Broad Bean, Biological control, Bioactivity

\section{INTRODUCTION}

Broad bean is commonly known as broad bean or field bean which is grown in winter. Total cultivated area in the world about 25.2 million hectares with 19.7 million tones total production per year. Many countries such as Mediterranean, Middle Easter, Chinese, Indian, African and South American use bean as a standard source of their diet, in addition, it has an impressive importance as inexpensive and protein and carbohydrates rich substance [1, 2].Broad bean can be consumed as vegetable as fresh, but if dry seeds and pods was needed the plants will be leaved in the field until the maturity of the pods when it became dry. They contain fibers, carbohydrates, vitamins, proteins and minerals) in addition to (phytic acid alkaloids, saponins and tannins was previously studied [3,4]. Several herbivores and pathogens will infect faba bean which consequently absorb nutrient and energy from plants. Aphid is considered one of the world-wide insect pests attacking faba bean and destroying most of the yields. There are about four thousand species were found and about two hundred and fifty species from this pests are harmful to different crops as well as the ornamental plants. One of them is Black bean aphid (Aphis fabae Scop.) is a major polyphagous pest of agricultural crops. The pest can cause to death of plants and causes reductions in the yield quantity and quality. Field losses infested by this pest can reach above 50\% [5]. This insect pierce leaves, stems, flowers and young pods during adulthood and nymphs and leads to yellowing plants, withering and dying. Furthermore, it is a vector of more than 30 plant viruses, such as those of tomato and peas, potato, beets, cucurbits, crucifers etc. [6]. Aphis fabae is often control by application of the insecticides which are highly expensive and toxic [7]. Results show that insect resistance against pesticides has been increased [8] Pesticides may cause the destruction of useful insects (pollinators, parasitoids and predators), as well as their disadvantages against humans and wildlife ecosystems [9], Therefore, it is necessary to seek for an alternative of managing procedure of the insect. Fertility management practices is the best way for soil amendment as it could change up-take of organic matter and nutrients by plants and also affect soil microorganism and soil-borne pathogens[10]. Moreover, soil O.M and macro-micronutrients encouraged changes in the soil biota [11] and it impact on the aphid in an indirect way which may reform the plant media and create better relationship between soil pathogen and the aphid insect. During previous year's, some new bioactive plant extracts were examined and found that they have insecticidal properties and safe ecologically [12]. It has been found that there are more than 2000 plant species belong to 170 families which possess insecticidal properties [13]. Different parts of the herbaceous plant (dried+ fresh) were used $[14,15]$. Few researches concerning this matter in Iraq-Kurdistan Region. In last decades bioactivity of botanical extracts against aphid species investigated by researchers. Among them, Aphis fabae [16, 17; 18; 19; 20; 21], Aphis citricola [22] Aphis craccivora [23], Aphis gossypii [24; 16, 17], Aphis nerii [16], Brevicoryne brassicae [24, 25], Lipaphis erysimi [26; 27], Melanocallis caryaefoliae [28], Myzus persicae $[29 ; 16,17 ; 30 ; 31 ; 32]$ and Schizaphis graminum [12]. Also, the plant extract repellent property vs. aphids was largely studied, among the aphid species, Aphis gossypii [33], Brevicoryne brassicae [24], and Myzus persicae $[29 ; 30 ; 16]$.

The aim of this study is to investigate the effect of different plant extracts based on dry matter of Eucalyptus, Onion, Garlic and Cinnamon for the control of black bean aphid. 


\section{METHODS AND MATERIALS}

\subsection{Experimental Site:}

This study was carried out at Bakrajo Technical Institute- Sulaimani Polytechnic University (SPU), Iraqi Kurdistan Region during (2015-2016) and (2016-2017) seasons under the rainfall condition. The location is at $\left(35^{\circ} 32.976 " \mathrm{~N}\right.$ latitude and $45^{\circ} 21.537^{\prime \prime}$ longitude), located at $8 \mathrm{~km}$ south Sulaimani. Averages of just four months of rainfall as well as maximum and minimum temperatures, relative humidity and wind rates are shown in table 1 .

Table 1: Bakrajo Environmental conditions:

\begin{tabular}{lcc}
\hline Parameters & $\begin{array}{c}\mathbf{2 0 1 6} \\
\text { (Average 4 } \\
\text { month) }\end{array}$ & $\begin{array}{c}\mathbf{2 0 1 7} \\
\text { (Average 4 } \\
\text { month) }\end{array}$ \\
\hline Rain $(\mathrm{mm})$ & 81.22 & 85.75 \\
Maximum Temp. $\left({ }^{\circ} \mathrm{C}\right)$ & 17.2 & 16.4 \\
Minimum Temp. $\left({ }^{\circ} \mathrm{C}\right)$ & 11.3 & 4.91 \\
Relative Humidity $(\%)$ & 23.2 & 25.9 \\
Wind $(\mathrm{km} / \mathrm{h})$ & 5.6 & 6.04 \\
\hline
\end{tabular}

\subsection{Preparation of Botanical Extracts:}

100 grams of dried materials for each of Eucalyptus (Eucalyptus sp) ET1, Onion (Allium cepa Linn) ET2, Garlic (Allium sativum) ET3 and Cinnamon (Cinnamomum sp) ET4, were grinded to fine powder by an electric mixer for 5 minutes separately, then each was soaked in one liter of water. \%100 of extracts preserved in well-dark cleaned glass bottles provided with tags at $25{ }^{\circ} \mathrm{C}$ which is a room temperature for twenty-four hours. After this period the mixtures were filtered through Whitman filter paper separately and stock of distilled water was also prepared to obtain required concentration (0, 1and 3\%) ER1, ER2, and ER3.Then immediately used to perform the experiments respectively.

\subsection{Application of Extracts in Field:}

Seeds of local variety of faba bean were sown by hand drill method and successive seedlings were grown in $3 \mathrm{X} 2 \mathrm{~m}$ individual field-plots. When the plant height reached $20-25 \mathrm{~cm}$, the field of the experiment were checked once a week for observing signs and symptoms of the aphids and recording any damages happened until it reaches the level of the economic threshold. Number of aphid (both immature and adults) were recorded on the indicated shoots $(10 \mathrm{~cm}$ apical). The following parameters were taken: number of aphids/plant (before and after botanicals spray), Plant Height $(\mathrm{PH}) \mathrm{cm}$, Fresh Weight.Plant ${ }^{-1}$ (FWP) g, Dry Weight.Plant ${ }^{-1}$ (DWP) g,
Number of Pods. Plant ${ }^{-1}$ (NPP). The counting aphid dead numbers individually (Mortality) were also taken after 6 hours $\left(\mathrm{M} 6^{\mathrm{h}}\right)$ and 24 hours $\left(\mathrm{M} 24^{\mathrm{h}}\right)$ spraying.

\subsection{Soil Properties:}

Physicochemical properties for the soil was determined for each season. Table 2 shows some of these properties defined by [34 and 35]. Physicochemical characteristics were determined following procedures described by [37, $38,39,40$, and 41].

Table 2: physicochemical properties of the soil used in the study:

\begin{tabular}{lll}
\hline Parameters & $\mathbf{2 0 1 6}$ & $\mathbf{2 0 1 7}$ \\
\hline $\mathrm{pH}$ & 7.65 & 7.5 \\
Electric Conductivity $(\mathrm{mmhos} / \mathrm{cm})$ & 2.0 & 2.12 \\
Calcium Carbonate $(\%)$ & 2.45 & 2.49 \\
Organic matter $(\%)$ & 2.30 & 2.48 \\
Calcium $\left(\mathrm{mgkg}^{-1}\right)$ & 4521 & 4322 \\
Magnesium $\left(\mathrm{mgkg}^{-1}\right)$ & 223.2 & 280.78 \\
potassium $\left(\mathrm{mgkg}^{-1}\right)$ & 203 & 245 \\
phosphor $\left(\mathrm{mgkg}^{-1}\right)$ & 4.07 & 3.47 \\
Zinc $\left(\mathrm{mgkg}^{-1}\right)$ & 1.43 & 1.37 \\
Manganic $\left(\mathrm{mgkg}^{-1}\right)$ & 27.2 & 35 \\
\hline
\end{tabular}

\subsection{Statistical Analysis:}

Factorial experiment in Randomized Complete Block Design (RCBD) with four replicates was used in order to test main and interaction effects of Seasons, four plant extractions and three applications rates. Analysis of variance was carried out for the data using JMP statistical discovery and the means were compared according to LSD at 0.05 level. Correlation between mean values was analyzed by (SPSS program version 20.0.0).

\section{RESULTS}

The results of ANOVA for the seasons, application of dissimilar plant extractions, extractions rate, and their interactions in regard to some measured aphid death and plant features are shown in Table 3. There was a significant effect of the treatments on most of the measured parameters in the broad beans plant except for $\mathrm{PH}$, and NP which were non-significantly affected by seasons. The interaction effect of the $\mathrm{S} \times \mathrm{ET}$, and $\mathrm{S} \times \mathrm{ET} \times \mathrm{ER}$ for the $\mathrm{M} 6^{\mathrm{h}}, \mathrm{M} 24^{\mathrm{h}}$, and $\mathrm{PH}$, and the interactions between $\mathrm{S} \times \mathrm{ER}$ for the $\mathrm{M} 24^{\mathrm{h}}, \mathrm{PH}$, and NP, were also non- significant.

Table 3: The ANOVA results of the treatments and their interactions for the effect plant extracts from different plants against $A$. fabae.

\begin{tabular}{|c|c|c|c|c|c|c|c|c|c|c|c|c|c|}
\hline \multirow{2}{*}{$\begin{array}{l}\text { Parameters } \\
\text { Source }\end{array}$} & \multirow[b]{2}{*}{ D.F } & \multicolumn{2}{|c|}{$\begin{array}{c}\text { Mortality After } \\
\mathbf{6 h} \\
(\%) \\
\end{array}$} & \multicolumn{2}{|c|}{$\begin{array}{c}\text { Mortality After } \\
\mathbf{2 4 h} \\
(\%)\end{array}$} & \multicolumn{2}{|c|}{$\begin{array}{c}\text { Plant } \\
\text { Height } \\
\text { (cm) }\end{array}$} & \multicolumn{2}{|c|}{$\begin{array}{c}\text { Fresh } \\
\text { Weight/Plant } \\
(\mathrm{g}) \\
\end{array}$} & \multicolumn{2}{|c|}{$\begin{array}{c}\text { Dry } \\
\text { Weight/Plant } \\
(\mathrm{g})\end{array}$} & \multicolumn{2}{|c|}{$\begin{array}{c}\text { No. of } \\
\text { Pods/Plant }\end{array}$} \\
\hline & & F-Ratio & $P>F$ & F-Ratio & $P>F$ & $F-$ Ratio & $P>F$ & F-Ratio & $P>F$ & F-Ratio & $P>F$ & F-Ratio & $P>F$ \\
\hline eason $(\mathrm{S})$ & 1 & 104.108 & 0.000 & 12.3909 & 0.012 & 2.7326 & 0.149 & 440.9326 & 0.000 & 249.9261 & 0.000 & 1.7263 & 0.236 \\
\hline Extractions Type (ET) & 3 & 308.7971 & 0.000 & 314.3005 & 0.000 & 7.7259 & 0.000 & 38.9103 & 0.000 & 63.1768 & 0.000 & 14.013 & 0.000 \\
\hline Extractions Rate (ER) & 2 & 1382.834 & 0.000 & 1437.707 & 0.000 & 43.2872 & 0.000 & 178.0183 & 0.000 & 262.0481 & 0.000 & 103.4472 & 0.000 \\
\hline $\mathrm{S} \times \mathrm{ET}$ & 3 & 0.9517 & 0.420 & 0.5561 & 0.645 & 1.5689 & 0.205 & 7.703 & 0.000 & 7.5872 & 0.000 & 4.0822 & 0.010 \\
\hline $\mathrm{S} \times \mathrm{ER}$ & 2 & 4.3473 & 0.016 & 0.716 & 0.492 & 2.8628 & 0.064 & 3.5828 & 0.033 & 13.0696 & 0.000 & 2.4173 & 0.097 \\
\hline $\mathrm{ET} \times \mathrm{ER}$ & 6 & 74.4139 & 0.000 & 76.8073 & 0.000 & 3.0819 & 0.010 & 11.1089 & 0.000 & 15.6004 & 0.000 & 3.5743 & 0.004 \\
\hline $\mathrm{S} \times \mathrm{ET} \times \mathrm{ER}$ & 6 & 0.7151 & 0.638 & 0.8193 & 0.558 & 1.8824 & 0.096 & 2.9858 & 0.012 & 2.809 & 0.017 & 2.7341 & 0.019 \\
\hline
\end{tabular}


Table 4 shows that different plant extracts have significant effects on all parameters. While $\mathrm{ET}^{1}$ gave maximum mortality after $6 \mathrm{~h}(49.03 \%), 24 \mathrm{~h}$ (52.21\%), $\mathrm{ET}^{4}$ gave the minimum percent of the motility which were $14.96 \%$ and $16.17 \%$ after $6 \mathrm{~h}$ and $24 \mathrm{~h}$, respectively.
$\mathrm{ET}^{1}$ and $\mathrm{ET}^{2}$ gave maximum plant height $(55.33 \mathrm{~cm})$ and fresh weight.plant ${ }^{-1}(82.25 \mathrm{~g})$, respectively, while $\mathrm{ET}^{4}$ gave minimum dry weight.plant ${ }^{-1}(7.54 \mathrm{~g})$ and No. of pods.plant ${ }^{-1}(5.17 \mathrm{~g})$.

\begin{tabular}{|c|c|c|c|c|c|c|}
\hline $\begin{array}{c}\text { Extractions Type } \\
\text { (ET) } \\
(\%) \\
\end{array}$ & $\begin{array}{c}\text { Mortality After } \\
\mathbf{6 h} \\
(\%) \\
\end{array}$ & $\begin{array}{c}\text { Mortality After } \\
\mathbf{2 4 h} \\
(\%) \\
\end{array}$ & $\begin{array}{c}\text { Plant } \\
\text { Height } \\
\text { (cm) }\end{array}$ & $\begin{array}{c}\text { Fresh } \\
\text { Weight/Plant } \\
(\mathrm{g}) \\
\end{array}$ & $\begin{array}{c}\text { Dry } \\
\text { Weight/Plant } \\
(\mathrm{g}) \\
\end{array}$ & $\begin{array}{c}\text { No. of } \\
\text { Pods/Plant }\end{array}$ \\
\hline $\mathrm{ET}^{1}$ & $49.083^{\mathrm{a}}$ & $52.208^{\mathrm{a}}$ & $55.333^{\mathrm{a}}$ & $77.000^{\mathrm{b}}$ & $11.300^{\mathrm{a}}$ & $7.416^{\mathrm{a}}$ \\
\hline $\mathrm{ET}^{2}$ & $35.791^{\mathrm{b}}$ & $38.541^{\mathrm{b}}$ & $52.208^{\mathrm{a}}$ & $82.250^{\mathrm{a}}$ & $11.033^{\mathrm{a}}$ & $7.125^{\mathrm{a}}$ \\
\hline $\mathrm{ET}^{3}$ & $31.958^{c}$ & $33.583^{c}$ & $52.708^{\mathrm{a}}$ & $78.083^{b}$ & $11.345^{\mathrm{a}}$ & $7.416^{\mathrm{a}}$ \\
\hline $\mathrm{ET}^{4}$ & $14.958^{d}$ & $16.166^{\mathrm{d}}$ & $46.291^{b}$ & $61.125^{\mathrm{c}}$ & $7.537^{\mathrm{b}}$ & $5.166^{\mathrm{b}}$ \\
\hline LSD & 2.259 & 2.371 & 3.877 & 4.197 & 0.657 & 0.818 \\
\hline
\end{tabular}

*Numbers within a column carrying the same letters are not different significantly according to (LSD, p < 0.05)

Table 5 shows that $\mathrm{ER}^{3}$ significantly increased mortality after $6 \mathrm{~h}(48.84 \%)$ and $24 \mathrm{~h}(52.38 \%)$. Minimum $\mathrm{PH}$ (42.63cm), FWP (54.78g), DWP (6.54g) and NP (3.84) obtained from the control $\left(\mathrm{ER}^{1}\right)$.

Table 5: Effects of botanical extract rate on Aphid mortality (\%) and yield performance of broad bean plants.

\begin{tabular}{|c|c|c|c|c|c|c|}
\hline $\begin{array}{c}\text { Extraction Rate } \\
\text { (ER) } \\
(\%)\end{array}$ & $\begin{array}{c}\text { Mortality After } \\
\mathbf{6 h} \\
(\%)\end{array}$ & $\begin{array}{c}\text { Mortality After } \\
\mathbf{2 4 h} \\
(\%)\end{array}$ & $\begin{array}{l}\text { Plant } \\
\text { Height } \\
(\text { cm) }\end{array}$ & $\begin{array}{c}\text { Fresh } \\
\text { Weight/Plant } \\
\text { (g) }\end{array}$ & $\begin{array}{c}\text { Dry } \\
\text { Weight/Plant } \\
\text { (g) }\end{array}$ & $\begin{array}{c}\text { No. of } \\
\text { Pods/Plant }\end{array}$ \\
\hline $\mathrm{ER}^{1}$ & $3.218^{\mathrm{c}}$ & $3.312^{\mathrm{c}}$ & $42.625^{\mathrm{b}}$ & $54.781^{b}$ & $6.537^{b}$ & $3.843^{\mathrm{b}}$ \\
\hline $\mathrm{ER}^{2}$ & $46.781^{b}$ & $49.687^{b}$ & $56.718^{a}$ & $84.781^{\mathrm{a}}$ & $12.225^{\mathrm{a}}$ & $8.031^{\mathrm{a}}$ \\
\hline $\mathrm{ER}^{3}$ & $48.843^{\mathrm{a}}$ & $52.375^{\mathrm{a}}$ & $55.562^{\mathrm{a}}$ & $84.281^{\mathrm{a}}$ & $12.150^{\mathrm{a}}$ & $8.468^{\mathrm{a}}$ \\
\hline LSD & 1.956 & 2.054 & 3.358 & 3.635 & 0.569 & 0.708 \\
\hline
\end{tabular}

Table 6 shows that all the parameters expect PH and NP significantly affected by growing seasons. Higher mortality\% after 6 and $24 \mathrm{~h}$ and DWP which were
$(35.08 \%),(36.25 \%)$ and $(12.74 \mathrm{~g})$, respectively obtained from the second season (S2), while higher FWP (85.00g) obtained from the first season

(S1).

Table 6: Effects of different seasons on Aphid mortality (\%) and yield performance of broad bean plants.

\begin{tabular}{|c|c|c|c|c|c|c|}
\hline Season & $\begin{array}{c}\text { Mortality After } \\
\mathbf{6 h} \\
(\%) \\
\end{array}$ & $\begin{array}{c}\text { Mortality After } \\
\mathbf{2 4 h} \\
(\%) \\
\end{array}$ & $\begin{array}{c}\text { Plant } \\
\text { Height } \\
\text { (cm) }\end{array}$ & $\begin{array}{c}\text { Fresh } \\
\text { Weight/Plant } \\
(\mathrm{g}) \\
\end{array}$ & $\begin{array}{c}\text { Dry } \\
\text { Weight/Plant } \\
\text { (g) } \\
\end{array}$ & $\begin{array}{c}\begin{array}{c}\text { No. of } \\
\text { Pods/Plant }\end{array} \\
\end{array}$ \\
\hline $\mathrm{S}^{1}$ & $30.812^{\mathrm{b}}$ & $34.000^{\mathrm{b}}$ & 52.500 & $85.000^{\mathrm{a}}$ & $7.782^{\mathrm{b}}$ & 6.937 \\
\hline$S^{2}$ & $35.083^{\mathrm{a}}$ & $36.250^{\mathrm{a}}$ & 50.770 & $64.229^{b}$ & $12.735^{\mathrm{a}}$ & 6.625 \\
\hline LSD & 1.024 & 1.564 & 2.559 & 2.420 & 0.752 & 0.581 \\
\hline
\end{tabular}

According to the maximum means, the best interactions of $\mathrm{M} 24^{\mathrm{h}}, \mathrm{PH}$, and NP $(78.000 \%, 68.250 \mathrm{~cm}$, and 10.750) respectively, were observed in $\mathrm{S}^{2} \times \mathrm{ET}^{1} \times \mathrm{ER}^{2}$, only for $\mathrm{M}^{\mathrm{h}}$ increases with $\mathrm{ER}^{3}$ (75.000). However, the $\mathrm{S}^{2} \times \mathrm{ET}^{3} \times \mathrm{ER}^{2}$, and $\mathrm{S}^{1} \times \mathrm{ET}^{2} \times \mathrm{ER}^{2}$ interactions were mostly affected to DWP, FWP $(17.875,114.500) \mathrm{g}$ respectively. Finally, the minimum value of all parameters was obtained by untreated plants (using distill water) in the experiment (Table 7).

Table 7: The best interaction between the season, extraction types, and extraction rates in the experiment.

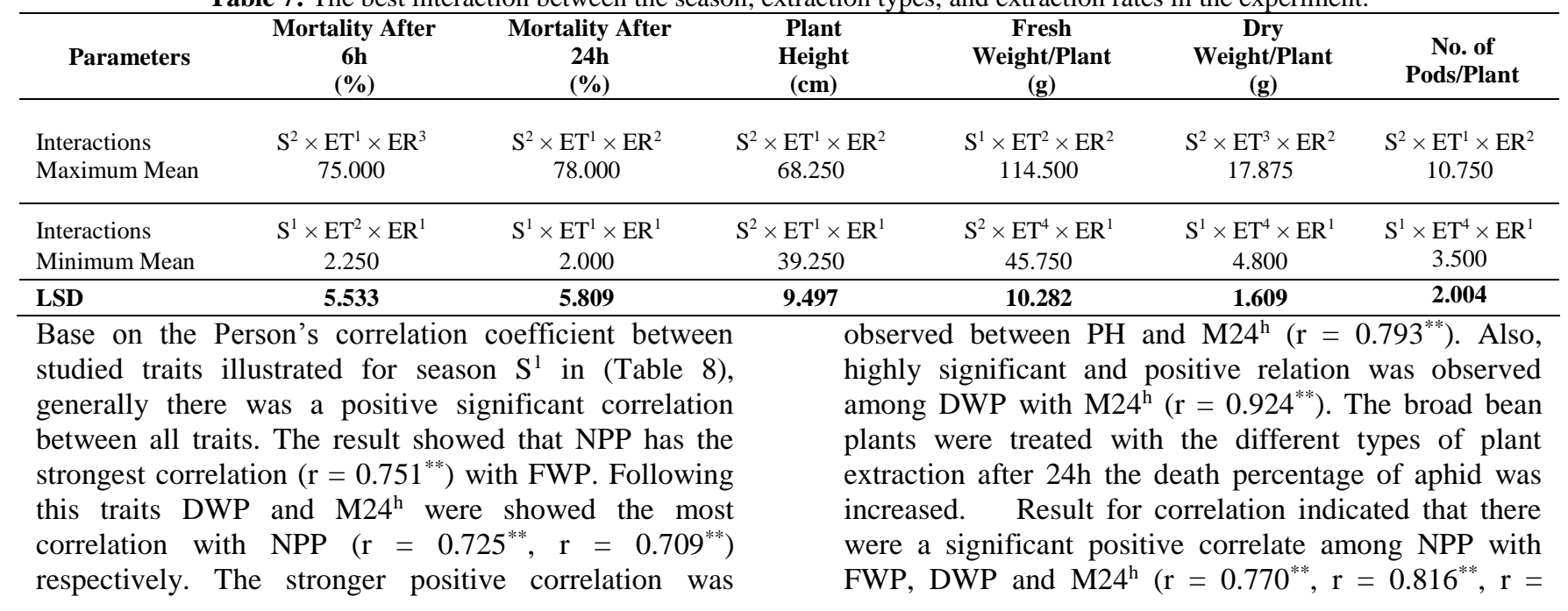


$\left.0.871^{* *}\right)$ respectively in $S^{2}$ (Table 9). Later this trait the FWP $\left(r=0.891^{* *}\right)$ and M24H $\left(r=0.892^{* *}\right)$ showed the strong correlation with DWP, although the same correlation was observed between FWP with $\mathrm{M}^{\mathrm{h}}$ and
$\mathrm{M} 24^{\mathrm{h}}\left(\mathrm{r}=0.819^{* *}\right)$. Finally, for both season a very strong positive correlation between $\mathrm{M} 24^{\mathrm{h}}$ and $\mathrm{M} 6^{\mathrm{h}}$ were observed.

Table 8: Correlation coefficients among Aphid mortality (\%) and yield performance of broad bean plants in 2015-2016.

\begin{tabular}{|c|c|c|c|c|c|c|}
\hline \multirow[b]{2}{*}{ Parameters } & \multicolumn{6}{|l|}{ Correlation with } \\
\hline & $\begin{array}{c}\text { Mortality After } \\
6 \mathbf{6 h} \\
(\%) \\
\end{array}$ & $\begin{array}{c}\text { Mortality After } \\
\mathbf{2 4 h} \\
(\%) \\
\end{array}$ & $\begin{array}{c}\text { Plant } \\
\text { Height } \\
(\mathrm{cm})\end{array}$ & $\begin{array}{c}\text { Fresh } \\
\text { Weight/Plant } \\
(\mathrm{g}) \\
\end{array}$ & $\begin{array}{c}\text { Dry } \\
\text { Weight/Plant } \\
(\mathrm{g})\end{array}$ & $\begin{array}{c}\text { No. of } \\
\text { Pods/Plant }\end{array}$ \\
\hline Mortality After 6h (\%) & 1 & & & & & \\
\hline Mortality After 24h (\%) & $0.994^{* *}$ & 1 & & & & \\
\hline Plant Height (cm) & $0.786^{* *}$ & $0.793^{* *}$ & 1 & & & \\
\hline Dry Weight/Plant (g) & $0.910^{* *}$ & $0.924^{* *}$ & $0.762^{* *}$ & $0.881^{* *}$ & 1 & \\
\hline No. of Pods/Plant & $0.698^{* *}$ & $0.709^{* *}$ & $0.688^{* *}$ & $0.751^{* *}$ & $0.725^{* *}$ & 1 \\
\hline
\end{tabular}

Table 9: Correlation coefficients among Aphid mortality (\%) and yield performance of broad bean plants in 2016-2017.

\begin{tabular}{|c|c|c|c|c|c|c|}
\hline \multirow[b]{2}{*}{ Parameters } & \multicolumn{6}{|l|}{ Correlation with } \\
\hline & $\begin{array}{c}\text { Mortality After } \\
6 \mathbf{6 h} \\
(\%) \\
\end{array}$ & $\begin{array}{c}\text { Mortality After } \\
\mathbf{2 4 h} \\
(\%)\end{array}$ & $\begin{array}{l}\text { Plant } \\
\text { Height } \\
(\mathrm{cm})\end{array}$ & $\begin{array}{c}\text { Fresh } \\
\text { Weight/Plant } \\
(\mathrm{g})\end{array}$ & $\begin{array}{c}\text { Dry } \\
\text { Weight/Plant } \\
\text { (g) }\end{array}$ & $\begin{array}{c}\text { No. of } \\
\text { Pods/Plant }\end{array}$ \\
\hline Mortality After $6 h(\%)$ & 1 & & & & & \\
\hline Mortality After 24h (\%) & $0.996^{* *}$ & 1 & & & & \\
\hline Plant Height (cm) & $0.692^{* *}$ & $0.699^{* *}$ & 1 & & & \\
\hline Dry Weight/Plant (g) & $0.888^{* *}$ & $0.896^{* *}$ & $0.592^{* *}$ & $0.891^{* *}$ & 1 & \\
\hline No. of Pods/Plant & $0.861^{* *}$ & $0.871^{* *}$ & $0.671^{* *}$ & $0.770^{* *}$ & $0.816^{* *}$ & 1 \\
\hline
\end{tabular}

${ }^{* *}$ Correlation is showing significances at 0.01 levels by using (2-tailed) test.

\section{DISCUSSION}

Application of materials such as water extract on the plant plays nowadays an important role in reducing aphid number which infests plants. Use of plant natural water extracts for the purpose of aphid control is of special concern in agriculture as they reduce environmental pollution compared to industrial compounds. Researchers have found that plant extracts are of noticeable influence on reducing aphid numbers and increasing yield in broad bean.

All botanical water extracts had effects on reduce of aphid numbers and increase morphological attribute with plant yield. Previous study evaluated water extract of eucalyptus and garlic reduced the number of aphids, also water extracts of tobacco and neem have been tested and showed a great result to control aphids [36].

Repelling activities of natural essential oils is of great importance in showing potential toxic action against aphids. Researchers found some properties of plant natural essential oils which are of special concern in controlling aphids among those are ginger (Zinigiber spp.), lavender (Lavandula officinalis Chaix), peppermint (Mentha piperita), spear-mint (Mentha spicata), thyme (Thymus vulgaris) and rosemary (Rosmarinus officinallis) oils [37, 38]. Among the 13 tested substance compounds contained in rosemary oil a repellent action in relation to Mentha persicae is exhibited by such compounds as linalool, d,1-camphor and terpineol.
According to [37] rosemary oil also gives repellent action when related to aphid of the cotton which is known as (Aphis gossypii Glover) and as well as the aphid of the potato plant (Macrosiphum euphorbiae Thomas), and the extraction of ginger oil.

\section{CONCLUSION}

Growing season, extraction types and rates influence the black bean aphid and thus resulted in the improving of quantity and quality of the yield. Eucalyptus plant extract gave the best effect in decreasing the number of aphid after 6 and 24 hours compared to the other plant extracts. Both $1 \%$ and $\% 3$ rates of extracts recorded better results in increasing mortality\%, plant height, fresh weight plant $^{-1}$, dry weight.plant ${ }^{-1}$ and number of pods. 2017 season was superior for increasing death number of aphid.

\section{References}

[1] I. Kubo, "New concept to search for alternate insect control agents from plants", In Elsevier: Naturally Occurring Bioactive Compounds 3, Eds., Rai, M. and M. Carpinella, Amsterdam, pp: 61-80, 2006.

[2] P. J. Pritchard, E. A. Dryburgh, and B. J. Wilson, "Carbohydrates of spring and winter field beans (vicia faba L.)," J. Sci. Food Agric., 24(6), pp. 663-668, 1973.

[3] C. L. Hedley, "Carbohydrates in grain legume seeds: Improving nutritional quality and agronomic characteristics", Wallingford: CABI, 2000.

[4] S. Multari, D. Stewart, and W. R. Russell, "Potential of Fava Bean as Future Protein Supply to Partially Replace Meat Intake in the Human Diet," Comprehensive Reviews In Food Science And Food Safety, 14(5) , pp. 511-522, 2015.

[5] L. M. Hansen, L. Lorentsen, and B. Boelt, "How to reduce the incidence of black bean aphids (Aphis fabae Scop.) attacking 
organic growing field beans (Vicia faba L.) by growing partially resistant bean varieties and by intercropping field beans with cereals," Acta Agriculturae Scandinavica, Section B - Soil \& Plant Science, 58(4), pp. 359-364, 2008.

[6] R. L. Blackman and V. F. Eastop, "Taxonomic issues, in Aphids as crop pests, H. F. van Emden and R. Harrington", Eds., Wallingford: CABI, pp. 1-29, 2007.

[7] M. J. Mihale, A. L. Deng, , H. O. Selemani, M. MugishaKamatenesi, , A. W. Kidukuli, J. O. Ogendo, "Use of Indigenous knowledge in the management of field and storage pests around Lake Victoria basin in Tanzania", African Journal of Environmental Science and Technology, 3(9): 251-259, 2009.

[8] J. O. Ogendo, S. R. Belmain, A. L. Deng, D. J. Walker, "Comparison of toxic and repellent effects of Lantana camara L. with Tephrosia vogelii hook and a synthetic pesticide against Sitophilus zeamais Motschulsky (Coleoptera: Curculionidae) in stored maize grain", Insect science and its Application, 23(2): 127-135, 2003.

[9] K. Ruchika, D. Kumar, "Occurrence and infestation level of sucking pests: Aphids on various host plants in agricultural fields of Vadora", Gujarat (India), 2012.

[10] P. C. Wall, S. M. Neate, R. D. Graham, D. J. Reuter, A. D. Rovira, "The effect of Rhizoctonia root disease and applied nitrogen on growth, nitrogen uptake and nutrient concentrations in spring wheat", Plant Soil; 163(1):111-20, 1994.

[11] W. Zhonge, T. Gu, W. Wang, B. Zhang, L. Xiangui, Q. Huang, W. Shen, "The effects of mineral fertilizer and organic manure on soil microbial community and diversity," Plant Soil, 326(12), pp. 511-522, 2010.

[12] T. D. Chermenskaya, E. A. Stepanycheva, A. V. Shchenikova, A. Sh. Chakaeva, "Insectoacaricidal and deterrent activities of extracts of Kyrgyzstan plants against three agricultural pests, Industrial Crops Products, 32: 157-163,2010.

[13] L. Feistein, "Insecticides from Plants Insect, year Book of Agriculture", U.S. D.A Washington, 222-229, 1952.

[14] E. Dankowska and J. Bendowska, "Further studies on the effect of plant infusions on the feeding of Deroceras laeve (O. F. Müller, 1774)," Folia Malac., 14(2), pp. 57-60, 2009.

[15] D. Emilie, M. Mallent, C. Menut, F. Chandre, and T. Martin, "Behavioral Response of Bemisia tabaci (Hemiptera: Aleyrodidae) to 20 Plant Extracts," (eng), Journal of economic entomology, 105(4), pp. 1890-1901, 2015.

[16] E. Salari, K. Ahmadi, and R. Zamani, "Study on the effects of acetonic extract of Otostegia persica (Labiatae) on three aphid species and one stored product pest," (English), Advances in Environmental Biology, 4(3), pp. 346-349, 2010.

[17] E. Salari, K. Ahmadi, R. Z. Dehyaghobi, A. Purhematy, and H. M. Takalloozadeh, "Toxic and Repellent effecto of Harmal (Peganum harmala L.) Acetonic Extract on Several Aphids and Tribolium castaneum (Herbst)," Chilean J. Agric. Res., 72(1), pp. 147-151, 2012.

[18] Z. A. Habou, A. Haougui, G. Mergeai , E. Haubruge , A. Toudou, , F. J. Verheggen, "insecticidal effect of Jatropha curcas oil on the aphid Aphis fabae (Hemiptera: Aphididae) and on the main insect pests associated with cowpeas (Vigna unguiculata) in Niger", Tropicultura, 29(4): 225-229, 2011.

[19] S. Mmbone, M. Mulaa, F. M. Wanjala, R. W. Nyukuri, E. Cheramgoi, "Efficacy of Tagetes minuta and Tephrosia vogelii crude leaf extracts on Tetranychus urticae (Acari: Tetranychidae) and Aphis fabae (Homoptera: Aphididae)", African Journal of Food Science and Technology, 5(8): 168173, 2014

[20] M. Rusin, L. Gospodarek, B. Binias, "The effect of water extracts from winter savory on black bean aphid mortality. Journal of Ecological Engineering, 17(1), Jan. 2016, pages 101-105, 2016

[21] B. Subedi, K. Acharya, K, Kafle, "Effectiveness of Plant Leaf Extract on Black Bean Aphid (Aphis fabae Linn.)," Innovative Techniques in Agricul-ture, 2(3) : 395-399, 2018.

[22] M. Larif, A. Zarrouk, A. Soulaymani, and A. Elmidaoui, "New innovation in order to recover the polyphenols of olive mill wastewater extracts for use as a biopesticide against the Euphyllura olivina and Aphis citricola," Res Chem Intermed, 39(9), pp. 4303-4313, 2013

[23] P. Baidoo, "Effects of Neem (Azadirachta indica A. Juss) Products on Aphis craccivora and its Predator Harmonia axyridis on Cowpea," AJEA, vol. 2, no. 2, pp. 198-206, 2012.

[24] A. Bagavan, C. Kamaraj, A. A. Rahuman, G. Elango, A. A
Zahir, G. Pandiyan, "Evaluation of larvicidal and nymphicidal potential of plant extracts against Anopheles subpictus Grassi, Culex tritaeniorhynchus Giles and Aphis gossypii Glover,' (eng), Parasitology research, 104(5), pp. 1109-1117, 2009.

[25] T. Shiberu and M. Negeri, "Effects of Synthetic Insecticides and Crude Botanicals Extracts on Cabbage aphid, Brevicoryne brassicae (L.) (Hemiptera: Aphididae) on Cabbage," J Fertil Pestic, 7(1), 2016.

[26] H.Arya, B. R. Singh, K. Singh, "Insecticidal activity of petroleum ether extract of castor seeds against mustard aphid Lipaphis erysimi Kaltenbach", Advances in Bioresearch, 5(1): 165-168, 2014.

[27] M. Sable, R. K. Kushwaha, "Efficacy of different plant leaf extract against mustard aphid Lipaphis erysimi (Kalt)", Journal of Industrial Pollution Control, 30(2): 231-233, 2014.

[28] M. Marín-Domínguez, R. Pérez-Leal, A. Núñez-Barrios, M. Basurto-Sotelo, and J. M. Soto-Parra, "Exposition of Pecan Black Aphid (Melanocallis caryaefoliae) to creseote bush (Larrea tridentata) extracts," AS, 5(14), pp. 1369-1375, 2014.

[29] R. Pavela, N. Vrchotova, B. Sera, "Repellency and toxicity of three Impatiens species (Balsaminaceae) extracts on Myzus persicae Sulzer (Homoptera: Aphididae)", Journal of Biopesticides, 2(1): 48-51, 2009.

[30] H. Ikeura, F. Kobayashi, and Y. Hayata, "Repellent Effect of Herb Extracts on the Population of Wingless Green Peach Aphid, Myzus persicae Sulzer (Hemiptera: Aphididae)," JAS, 4(5), 2012.

[31] A. B. Hamouda, , K. Zarrad, , A. Laarif, , I. Chaieb, Insecticidal effect of Solanum elaeagnifolium extracts under laboratory conditions, Journal of Entomology and Zoology Studies, 3(3): 187-190, 2015.

[32] B. NIA, N. FRAH, and I. AZOUI, "Insecticidal activity of three plants extracts against Myzus persicae (Sulzer, 1776) and their phytochemical screening," aas, vol. 105, no. 2, pp. 261-267, 2015 .

[33] A. Singh, R. Kataria, D. Kumar "Repellence property of traditional plant leaf extracts against Aphis gossypii Glover and Phenacoccus solenopsis Tinsley," Afr. J. Agric. Res., 7(11), 2012.

[34] M. A. Ali and A. J. Mjeed, "Biochar and Nitrogen Fertilizers Effects on Growth and Flowering of Garland Chrysanthemum (Chrysanthemum Coronarium L.) Plant," KJAR, 2(1), pp. 8-14, 2017.

[35] A. J. Mjeed, M. A. Ali, "Effect of Gyttja and Nitrogen Applications on Growth and Flowering of Snapdragons (Antirrhinum majus L.) Plant in the Two Soils Depth," KJAR, 2(1), pp. 1-7, 2017.

[36] Md. Habibullah Bahar, Md. Aminul Islam, and Md. Abdul Mannan and Md. Jashim Uddin, "Effectiveness of some botanical extracts on bean aphids attacking yard-long beans," no. 4(2), 2007.

[37] M. Hori, "Repellency of rosemary oil against Myzus persicae in a laboratory and in a screen house", J. Chem. Ecol., 24, 14251432, 1998.

[38] M. Hori, "The effects of rosemary and ginger oils on the alighting behavior of Myzus persicae (Sulzer) (Homoptera: Aphididae) and on the incidence of yellow spotted streak," Appl. entomol. Zool, 34(3), pp. 351-358, 1999. 